UCRL- 9935

PREPRINT

\author{
REPRODUCED FROM \\ BEST AVAILABLE COPY
}

HUMAN DNA REPAIR AND RECOMBINATION GENES

\author{
Larry H. Thompson \\ Christine A. Wober \\ Nigel J. Jones
}

\begin{abstract}
BIOMEDICAL SCIENCES DIVISION
This paper will be publlahed as a Chapter

In the Procesdinge of the NATO Advanced Rosearch Workshop on DNA Repalr Mechenlems and Their Blologleal Implleations

In Mammallan Colts

October 2-7, 1988

Fontovraud, France
\end{abstract}

Septomber 1988
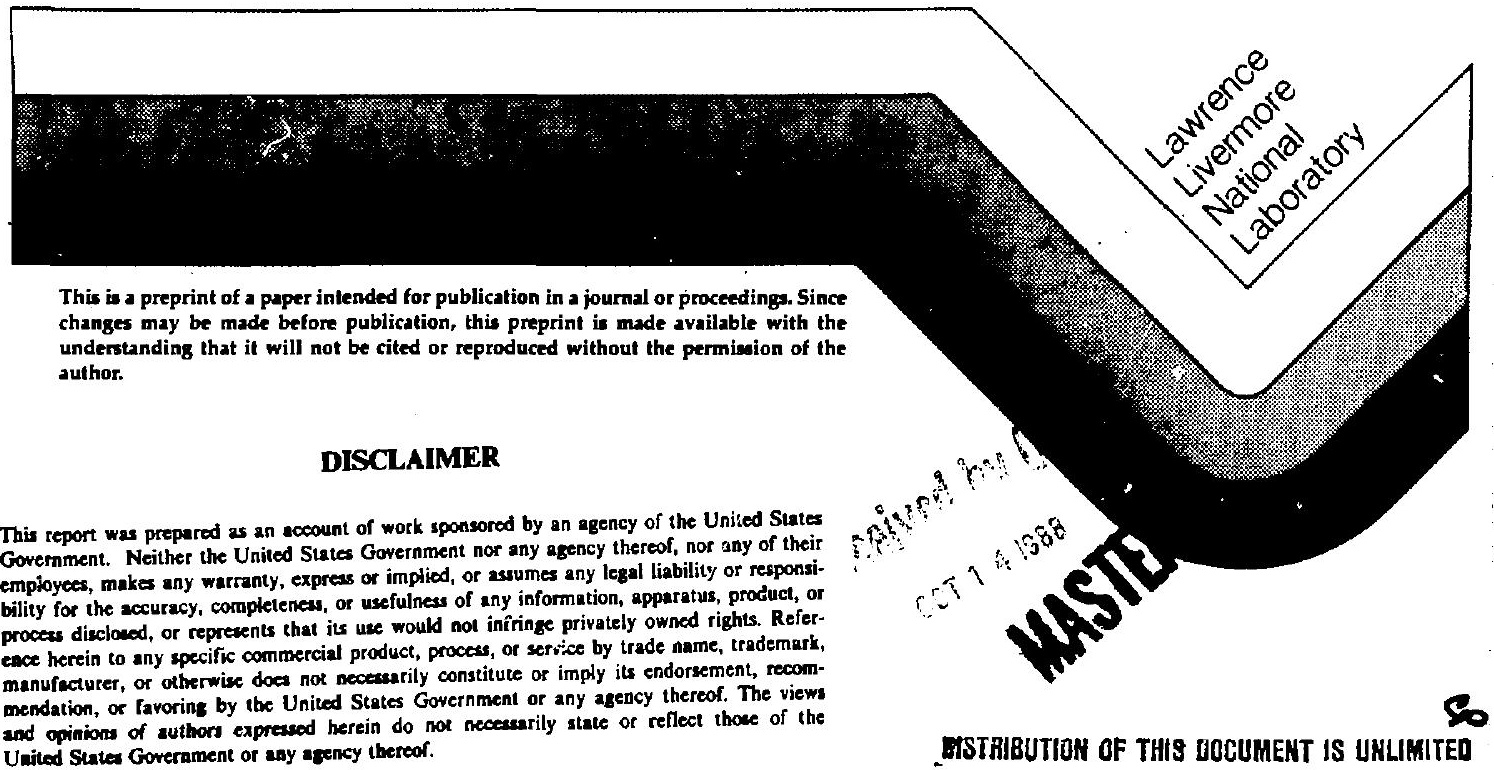
UCRL--98935

DE8S 001122

\title{
HUMAN DNA REPAIR AND RECOMBINATION GENES
}

\author{
Larry H. Thompson, Christine A. Weber, and Nigel J. Jones \\ Biomedical Sciences Division \\ Lawrence Livermore National Laboratory \\ P.O. Box 5507 \\ Livermore, Califomia 94550
}

\begin{abstract}
Several genes involved in mammalien DNA repair pathways were identified by complementation analysis and chromosomal mapping based on hybrid cells. Eight complementation groups of rodent mutants defective in the repair of $\mathrm{UV}$ radiation damage are now identified. At least seven of these genes are probably essential for repair and at least six of them control the incision step. The many genes required for repair of DNA cross-linking damage show overlap with those involved in the repair of UV damage, but some of these genes appear to be unique for cross-link repair. Two genes residing on human chromosome 19 were cloned from genomic transformants using a cosmid vector, and near full-length cDNA clones of each gene were isolated and sequenced. Gene ERCC2 efficiently corrects the defect in CHO UV5, a nucleotide excision repair mutant. Gene $X R C C I$ normalizes repair of strand breaks and the excessive sister chromatid exchange in CHO mutant EM9. ERCC2 shows a remarkable $-52 \%$ overall homology at both the amino acid and nucleotide levels with the yeast RAD3 gene. Evidence based on mutation induction frequencies suggests that $E R C C 2$, like $R A D 3$, might also be an essential gene for viability.
\end{abstract}




\section{INTRODUCTIOR}

Unrepaired damage to the DNA molecules in somatic cells will likely produce mutations if DNA replication preceeds repair of the damage. Mutations are generally assumed to be the starting point for cellular changes that can lead to malignancy. The critical relationship between repair and carcinogenesis is borne out by the studies of human genetic disorders such as xeroderma pigmentosum (XP), ataxia telangiectasia, and Bloom's syndrome, which have various defects in the repair or related metabolism of DNA (Hanawalt and Sarasin, 1986; Friedberg, 1985). Individuals with these disorders have a substantially increased predisposition to cancer. Thus, DNA repair pathways must play an essential role in maintaining genetic integrity and the growth controls that ensure cellular differentiation.

In order to understand how cells respond to DNA damage, it is necessary to determine the genetic and biochemical details of particular repair pathways. A major pathway is nucleotide excision repair, which acts on bulky chemical adducts and photoproducts from ultraviolet (UV) radiation, i.e. cyclobutane dimers and pyrimidine(6-4)pyrimidone $[(6-4)]$ photoproducts. This pathway has been the focus of much study in different organisms. In $E$. coli, the $u v r A, u v r B$, and $u v r C$ gene products are essential for the initial damage recognition and incision step (Friedberg, 1985; 1987). In the small eukaryote $S$. cerevisiae, five genes are absolutely required for incision, and at least five other genes appear to be involved in the pathway but are not essential for incision (Friedberg, 1985; 1987).

For mammalian cells we do not yet have a good estimate of the number of genes participating in the incision step of nucleotide excision repair, but the number appears to be larger than in yeast. In XP cell lines, nine complementation groups have been reported in which there are varying degrees of repair deficiency in this pathway (Fischer et al., 1985). A recent study presents evidence that the groups designated D and $\mathrm{H}$ may, in fact, be allelic as direct measurement of repair incision failed to show complementation in hybrid cells derived from these groups (Johnson et al., 1988). 
To facilitate studying various repair pathways, many laboratories have isolated mutant lines on the basis of hypersensitivity to DNA damaging agents. The first reports of mutants having pronounced sensitivity (2-10 fold) were isolated in CHO (Chinese hamster ovary) cells, a line widely used for genetic studies (Gottesman, 1985). These mutants showed enhanced killing with UV radiation, ethyl methanesulfonate, or mitomycin C (Thompson et al., 1980; Busch et al., 1980). Since then, a great variety of mutant lines that show hypersensitivity to DNAdamaging agents have been obtained in the near-diploid CHO and V79 hamster lines (see review by Hickson and Harris, 1988), as well as in mouse lymphoma and other cell lines (reviewed by Collins and Johnson, 1987). One recent report, based on screening simultaneously for a variety of mutagen-sensitive phenotypes, described a very high induced mutant frequency of $2 \times 10^{-2}$ (Zdzienicka et al., 1987), which may be due to the partial hemizygosity of the V79 cells (Thacker, 1981).

The isolation and classification of mutants into complementation groups has now greatly exceeded the rate at which mutants are being characterized at the molecular level. For a few mutants, some identification of the nature of the biochemical defects has been achieved, i.e. defects in single-strand or double-strand break rejoining, alteration in polymerase alpha, defective incision at bulky adducts, or altered topoisomerase II [see Table 1 in Hickson and Harris (1988)]. In this article we discuss recent developments toward cloning and characterizing mammalian DNA repair genes, as well as recent information about the biochemical defects in several mutant cell lines that are currently being investigated.

\section{RESULTS AND DISCUSSION}

Complementation Groups of Mutations Affecting Nucleotide Excision Repair

One of cur goals has been the identification of new complementation groups of mammalian cell mutants that are likely to be defective in nucleotide excision repair. A summary of these complementation studies is given in Table 1. Initially our laboratory described four groups based on a high degree of UV sensitivity, with emphasis on mutant lines UV20, UV5, UV24, and 
UV41, and later a fifth group (UV135), all of which were isolited in CHO cells. The representative mutants from each of the groups had little or no repair activity in response to UV radiation and all showed marked sensitivity in terms of cell killing and mutation induction (Busch et al., 1980; Thompson et al., 1980; 1981; 1982a). The similar degree of hypersensitivity and the observed complemertation suggested that each mutation affects a different gene in the same pathway; each gene appears necessary for incision to occur (Thompson et al., 1982a). Presumably each mutation inactivated a protein essential for repair function. Subsequently, a sixth complementation group for UV sensitivity was identified in CHO (Thompson et al., 1987b), but this line (UV61) was appreciably less sensitive than the representative members of groups 1 through 5.

Mutant UV61 was recently studied in more detail and some insight was obtained concerning its intermediate UV sensitivity (Thompson et al., 1988c). Using a radioimmunoassay for (6-4) photoproducts, repair of these lesions appears to be normal in UV61. However, using a chromatographic assay, no removal of cyclobutane dimers from bulk DNA could be detected during $24 \mathrm{~h}$ postirradiation, indicating that this defect is likely responsible for the 2.5-fold hypersensitivity of this mutant (Thompson et al., 1988c). The rate of strand incision during the first 90 min after UV irradiation was normal in UV61, suggesting that the repair seen in normal cells at early times can be attributed predominantly to (6-4) photoproducts. It is presently unclear whether UV61 has any repair activity for cyclobutane dimers in actively transcribed genes. If not, then this mutant provides a particularly useful system for evaluating the relative contributions of these two major classes of UV photoproducts to cell killing, mutation, and other biological endpoints.

Knowing the reason for the partial repair activity seen in UV61 is of much importance. In general, a mutant phenotype could arise from a cell having both a normal and a mutant allele. However, since mutations affecting repair are usually recessive in cell hybrids, we shall assume that residual repair capacity reflects the expression of only a mutant allele. One possibility with UV61 is that the hamster ERCC6 gene product is normally needed for the repair of cyclobutane 
dimers but not for (6-4) photoproducts. In this case the mutation may have fully inactivated the repair protein. A secord possibility is that the mutation is "leaky" and occurs in a protein that is normally required for repair of both classes of UV photoproducts. A partially defective protein may have lost its affinity for cyclobutane dimers, which are normally repaired poorly in bulk DNA of hamster cells, while maintaining its affinity for (6-4) photoproducts. In support of this idea is the isolation of a revertant of UV61 in which the mutant gene appears to have been amplified $\sim 10$-fold (J. Hoeijmakers, pe:sonal communication). Presumably by overproducing an altered protein product the revertant has restored repair activity sufficiently to produce normal UV resistance.

Table 1. Complementation Groups of UV-Sensitive Rodent Cell Lines

\begin{tabular}{llrrr}
\hline Group & \multicolumn{1}{c}{ Representatives } & $\begin{array}{c}\text { Degree of } \\
\text { UV-sen. }\end{array}$ & $\begin{array}{l}\text { Degree of } \\
\text { MMC-sen. }\end{array}$ & Refs. (resp. $^{\mathrm{b}}$ \\
\hline $1^{\mathrm{c}}$ & UV20, UV4, UVL10, 43-3B & 6 & 90 & $1,2,3,4$ \\
$2^{\mathrm{C}}$ & UV5, UV57, UVL1, V-H1 & 6 & 3.5 & $1,2,3,5$ \\
3 & UV24, 27-1, MMC-2 & 6 & 3.5 & $1,6,6$ \\
4 & UV41, UV47 & 6 & 90 & 1,2 \\
5 & UV135; Q31 & $6 ; 4$ & $3.5 ; 1.0$ & 7,8 \\
6 & UV61; US46 & $2.5 ; 4$ & $? ; 2.7$ & 6,9 \\
7 & V-B11 & 2 & 2 & 10 \\
8 & US31 & 4 & 4 & 9 \\
\hline
\end{tabular}

a In most instances the hypersensitivity refers to the first mutant listed. Numbers refer to ratio of $D_{0}$ 's or, in some cases with mitomycin $C$ (MMC), to the differential cytotoxicity ratio as defined by Hoy et al., 1985. For groups 5 and 6 , values are given for both hamster and mouse mutants.

b References indicate the studies in which the complementation group assignments were made:

1. Thompson et al., 1981.

3. G. Adair, personal comm.

5. Zdzienicka et al., 1988a.

7. Thompson and Carrano, 1983.

9. Thompson et al., 1988d.

2. Hoy et al., 1985.

4. Wood and Burki, 1982.

6. Thompson et al., 1987b.

8. Thompson et al., 1987a.

10. Zdzienicka et al., 1988b.

c The numbering of groups 1 and 2 was recently interchanged to correspond to the nuinbers of the complementing human genes, ERCCl and ERCC2: See announcement accompanying Thompson et al., 1988e. 
Another observation that is pertinent to understanding the biochemical defect in UV61 is its sensitivity to bulky chemical mutagens. With 7-bromomethylbenz[a]anthracene, the degree of hypersensitivity to killing is almost as great as in the mutant UV5 (Thompson et al., 1988c), which appears to be fully deficient in the removal of DNA adducts produced by this compound (Thompson et al., 1984). These results suggest that the normal protein encoded by the gene that is mutated in UV61 is an essential one for the nucleotide excision repair pathway. The mouse mutant US46, which also belongs to complementation group 6, appears to be fully repairdeficient, based on its degree of hypersensitivity to killing by UV radiation (Shiomi et al., 1982). From these observations we conclude that the ERCC6 gene appears to be essential for the nucleotide excision repair pathway.

Complementation groups 7 and 8 in Table 1 are each represented by single members isolated from V79 hamster cells and mouse lymphoma cells, respectively. The VB11 mutant shows only about 2-fold hypersensitivity and an intermediate level of incision after UV irradiation (Zdzienicka et al., 1988b), but there is no evidence as to whether this phenotype involves a leaky mutation in an essential gene or loss of function in a gene that is only partially required for repair. The mouse mutant line US31, while not characterized biochemically in terms of its repair defect, has a similar degree of UV sensitivity as the fully repair deficient (incision deficient) mutant Q31 (Sato and Setlow, 1981; Shiomi et al., 1982). These results suggest that the gene involved in complementation group 8 is also essential for the UV repair pathway. Thus, altogether, the preceeding results suggest that in rodent cells at least seven genes (ERCC1$E R C C 6$ and $E R C C 8$ ) are required for UV damage repair, which is two more than appear to be necessary in yeast.

\section{Chromosomal Mapping of Repair Genes}

The use of interspecific hybrid cells provides a valuable way to determine how well human genes can complement rodent mutations and, at the same time, to localize the complementing genes on specific chromosomes and ragions of chromosomes. We have obtained primary 
hybrids after cell fusion between rodent mutants and human lymphocytes by selecting for complementation of the repair defect. Selection against mutants defective in nucleotide excision repair has been performed using repeited exposure to UV radiation, or continual exposure to mitomycin $C(M M C)$ for mutants that show extreme hypersensittvity to this agent. Chromosomal analysis of a set of resistant hybrid clones (usually 20-30) will establish which human chromosome correlates with the repair proficient phenotype. Segregation of the complementing chromosome from resistant hybrids, by growth in normal medium, allows confirmation of the assignment by checking for the acquisition of sensitivity in such subclones. Breakage of the complementing chromosome occurs frequently in this system. However, this preperty can be used advantageously to localize a repair gene to a particular chromosomal region by analyzing hybrids that retain a small portion of the chromosome using previously mapped DNA probes.

A summary of chromosomal assignments for human repair genes made to date using rodent mutants is given in Table 2. Complementation groups 1 through 5 map to four different human chromosomes. Groups 1 and 2 are complemented by the genes ERCCI and ERCC2 respectively, both on chromosome 19. Recent results based on pulsed field gel electrophoresis indicate that these two genes are $<280 \mathrm{~kb}$ apart and contained on a single Notl restriction fragment (H. Mohrenweiser, personal communication). Whether this tight linkage of two genes irivolved in the same repair pathway has functional significance is unclear. In Table 2, ERCC gene numbers have been assigned to each of the human genes that complement, or which are expected to complement (ERCC7 and ERCC8), each of the UV sensitive rodent mutations. By comparison, the chromosomal assignment of the gene for only one XP group has been determined so far. XP-F cells were partially complemented to UV resistance by chromosome 15 in hybrids produced by microcell-mediated chromosome transfer (Schultz et al., 1988). In addition to the two nucleotide excision repair mutants discussed above, the EM9 mutant is also corrected by a gene (XRCCI) on human chromosome 19 (Siciliano et al., 1986). This. finding of three repair genes on chromosome 19 is at least partly a reflection of the fact the homologous 
loci lie on a hemizygous chromosome in CHO cells (Thompson et al., 1988a). Hemizygosity greatly favors the isolation of recessive mutations.

\section{Cloning and Characterization of ERCC Repair Genes}

Several of the human nucleotide excision repair genes (designated ERRC = Excision Repair Cross Complementing) listed in Table 2 have been cloned and characterized in some detail. The status of these cloning efforts is given in Table 3 . The first human repair gene to be cloned was $E R C C l$, obtained by screening a cosmid library made from a secondary transformant and probing for a closely linked plasmid marker sequence (Westerveld et al., 1984). A reconstructed, functional cDNA was obtained (van Duin et al., 1986), and the intron-exon junctions were determined (van Duin et al., 1987). ERCC2 was isolated in our laboratory

Table 2. Identifying and Mapping Human DNA Repair Genes Using Rodent Mutants

\begin{tabular}{lcccl}
\hline Mutant & UV Group & Chromosome & Referencea & Gene nameb \\
\hline UV20,43-3B & 1 & 19 & 1,2 & $E R C C 1$ \\
UV5 & 2 & 19 & 3 & $E R C C 2$ \\
UV24 & 3 & 2 & 4 & $E R C C 3$ \\
UV41 & 4 & 16 & 3 & $E R C C 4$ \\
UV135,Q31 & 5 & 13 & 4,6 & $E R C C 5$ \\
UV61 & 6 & ND & - & ERCC6 \\
VB11 & 7 & ND & - & ERCC7?d \\
US31 & 8 & ND & - & ERCC8?e \\
EM9 & -- & 19 & 5 & XRCC1 \\
\hline
\end{tabular}

References for chromosomal assignments:

1. Thompson et al., $1985 . \quad 2$. van Duin et al., 1986.

3. Siciliano et al., 1987. 4. Thompson et al., 1987a.

5. Siciliano et al., $1986 . \quad 6$. Hori et al., 1983.

b $X R C C=\mathrm{X}$-ray Repair Cross Complementing;

$E R C C=$ Excision Repair Cross Complementing

c $\mathrm{ND}=$ not determined

d Question marks signify that correction of the rodent mutation by a human gene has not yet been demonstrated.

- The mouse mutant US31 has not yet been evaluated for a presumptive defect in nucleotide excision repair. 
from the cosmid library of a secondary transformant by screening for human Alu- family repetitive sequences (Weber et al., 1988a; Thompson, 1988). However, this approach has proven not to be generally applicable since the genes ERCC4 (Dulhanty et al., 1988) and ERCC6, even though it is $\sim 100 \mathrm{~kb}$ (J. Hoeijmakers, personal communication), seem to lack repetitive elements of this type. In the case of ERCC3, a portion of the gene has been difficult to isolate (Weeda et al., 1988), but recently a functional cDNA clone of $2.9 \mathrm{~kb}$ was obtained from the Okayama pcD2 expression library (Chen and Okayama, 1987) (J. Hoeijmakers, personal communication). Efforts to isolate the cDNA of ERCC6 are ongoing (J. Hoeijmakers, personal communication).

A cDNA clone of ERCC2, isolated from the pcD2 expression library conferred partial UV resistance to UV5 cells $24 \mathrm{~h}$ after transfection, but did not confer stable resistance (Weber et al., 1988b). Analysis of the 5 ' end of the cosmid-bome genomic sequence isdicates that this cDNA contains part of an intron at its 5 ' end and lacks the first five base pairs of protein coding sequence as well as the 5'-untranslated region (Weber et al., 1988c). The deduced amino acid sequence of ERCC2 was found to have a striking $52 \%$ identity with the yeast RAD3 encoded protein, and the two encoded proteins are quite similar in length (760 a.a. vs. 778 a.a.). Several regions of $E R C C 2$ have at least $70 \%$ nucleotide homology with $R A D 3$. Since $\operatorname{Rad} 3$ is an essential protein for viability (Naumovski and Friedberg, 1983, 1986; Higgins et al., 1983) and has both ATPase activity (Sung et al.,1987b) and helicase activity (Sung et al., 1987a), the question arises as to whether $E R C C 2$ is also an essential gene. A comparison of mutation induction frequencies for point mutagens versus a frame-shift agent ICR170 in CHO cells has provided highly suggestive evidence that this mammalian gene is also essential (Busch et al., 1988). Point mutagens produced the expected relative recovery of mutants in complementation groups 1 and 2. However, when ICR 170 was used, the frequency of mutants recovered in complementation group 2 was 40 -fold lower than expected, relative to the frequency of mutants 
Table 3. Status of Cloning and Analyzing Human Repair Genes

\begin{tabular}{|c|c|c|c|c|c|}
\hline $\begin{array}{l}\text { Gene } \\
\text { name }\end{array}$ & Cloned? & References ${ }^{a}$ & $\begin{array}{l}\text { Homologous } \\
\text { gene in } \\
\text { S. Cerevisize }\end{array}$ & $\begin{array}{c}\text { Gene } \\
\text { size }\end{array}$ & $\begin{array}{l}\text { Size of } \\
\text { putative } \\
\text { protein }\end{array}$ \\
\hline $\begin{array}{l}E R C C 1 \\
E R C C 2 \\
E R C C 3 \\
E R C C 4 \\
E R C C 5 \\
E R C C 6 \\
E R C C 7 \\
E R C C 8\end{array}$ & $\begin{array}{l}\text { yes } \\
\text { yes } \\
\text { yes } \\
\text { no } \\
\text { no } \\
\text { partly } \\
\text { no } \\
\text { no }\end{array}$ & $\begin{array}{r}1,2,3 \\
4,5 \\
6 \\
7 \\
8 \\
9\end{array}$ & $\begin{array}{l}\text { RADIO } \\
\text { RAD3 } \\
? \\
?\end{array}$ & $\begin{array}{r}15 \mathbf{k b} \\
19 \mathbf{k b} \\
-100 \mathbf{k b}\end{array}$ & $\begin{array}{l}297 \text { a.a. } \\
760 \text { a.a. }\end{array}$ \\
\hline$X R C C I$ & yes & 10 & $?$ & $\sim 33 \mathrm{~kb}$ & \\
\hline
\end{tabular}

a References pertaining to gene cloning are as follows:
1. Westerveld et al., 1984.
3. Van Duin et al, 1987.
2. Van Duin et al., 1986.
5. Weber et al., $1988 \mathrm{c}$.
4. Weber et al., 1988a.
7. Dulhanty et al., 1988.
6. Weeda et al., 1988.
9. J.H.J. Hoeijmakers, personal comm.
8. MacInnes et al., 1988.
10. Thompson et al., 1988b.

induced in group 1. ICR170 would be expected to disrupt the hamster ERCC2 protein by producing premature termination codons, and thus lethal mutations, if a region of $E R C C 2$ has an essential function.

The ERCCl gene shows homology with the yeast gene RADI0. However, the encoded proteins differ considerably in size, and the homology is limited to certain regions (van Duin et al., 1986). Nevertheless, evidence has been presented that RAD10 can provide some restoration of the repair defect in the CHO mutants of (newly defined) complementation group 1 (Lambert et al., 1988). Thus, it is of considerable interest, in view of their similarity, to test whether RAD3 and $E R C C 2$ show any interchangeability of function. Looking ahead, the fact that the first two cloned human repair genes to be analyzed show homology with known yeast genes suggests that many other human genes will probably have counterparts in the yeast system. 
Thus, these results for $E R C C l$ and $E R C C 2$ point to a strong interspecies similarity of repair proteins. At the functional level, ERCC2 restored UV survival, mutation frequencies, and strand incision to levels that were indistinguishable from those of normal CHO cells (Weber et al. 1988a). $E R C C l$ gave less efficient, but very substantial, correction for cell survival with either UV radiation or MMC or for dimer removal (Westerveld et al., 1984; Zdzienicka et al., 1987). In addition, ERCC1 and ERCC2 were lested for specificity of complementation, and each gene corrected only CHO mutants in the complementation group that was used for isolating the gene (van Duin et al., 1988; Weber et al., 1988a).

\section{Cloning and Characterization of a Gene that Complements Mutant EM9}

Our laboratory also isolated the human gene identified as XRCCI (see Table 2), which corrects the CHO mutant EM9. EM9 cells are noted for their very high level of baseline sister chromatid exchange (SCE) and defective strand-break rejoining (Thompson et al., 1982b). All complementation studies have been performed using chlorcdeoxyuridine as the selective agent. XRCC1 was cloned from a cosmid library of a tertiary transformant (Thompson et al., 1987b; 1988b), and a functional cDNA clone was obtained from the pcD2 library (Chen and Okayama, 1987). Based on SCE frequency as a sensitive measure of complementation, two cosmid clones give $100 \%$ correction, but the cDNA clone consistently gives $\sim 80 \%$ correction (Thompson et al., 1988e). This correction is stable, unlike the transient correction seen with the incomplete cDNA of $E R C C 2$. The XRCCI genomic clones also efficiently correct the hypersensizivity of EM9 to ionizing radiation and completely restore the normal rate of strandEzeak rejoining after irradiation (Thompson et al., 1988b). Analysis of the nucleotide sequence of $X R C C l$ cDNA with respect to open reading frames and candidate translational start codons suggests that a portion of the protein coding region is missing at the $S^{\prime}$ end. This interpretation is consisteat with the incomplete correction obtain $\in=1$ in transformants. The efficient correction sesit with the gene itself suggests a repair protein having a high degree of conservation among mammals. 
Table 4. Hamster Mutants Having Pronounced Sensitivity to the Cross-Linking Agent MMC But Little or No UV Sensitivity

\begin{tabular}{llrrr}
\hline Mutant & Cell line & $\begin{array}{c}\text { Degree of } \\
\text { UV-sen.2 }\end{array}$ & $\begin{array}{c}\text { Degree of } \\
\text { MMC-sen. }\end{array}$ & Refs. a \\
\hline irs1SF & CHO & 2 & 100 & 1 \\
irs1 & V79 & $2-3$ & 50 & 2 \\
irs3 & V79 & 1 & 7 & 2 \\
V-C8 & V79 & 2 & 110 & 3 \\
V-H4 & V79 & 1 & 33 & 3 \\
V-H11 & V79 & 1 & 8 & 3 \\
UV-1 & CHO & 2 & 10 & 4,5 \\
MMC-1 & CHO & 1 & 5 & 6,7 \\
MCS & CHO & 1 & 8 & 8 \\
\hline
\end{tabular}

- References are us follows:

1. Fuller and Painter, 1988.

2. Jones et al., 1987.

3. Zdzienicka and Simons, 1987. 4. Stamato and Waldren, 1977.

5. Waldren et al., 1983.

6. Robson et al., 1985.

7. Robson and Fiickson, 1986.

8. Thompson et al., 1980.

Possible Role of ERCC2 in Excision Repair

A highly unusual feature of the mutants in UV complementation group 2 was recently recognized. In Table 1, four mutants are listed in this group, and they all have similar sensitivity to killing by UV radiacion. However, mutants V-H1 and UVL1 show intermediate levels of repair, while mutants UV5 and UV57 have no desectable repair (Mitchell et al., 1988; Zdzienicka et al., 1988). These properties suggest that mutants V-H1 and UVL1 are performing repair in a way that it is not biologically effective for restoring survival. Recent studies have shown that the survival of CHO cells correlates with repair of cyclobutane dimers in active genes (Bohr et al., $1985 ; 1986 ; 1987$ ). Very little repair seems to occur in bulk DNA in rodent cells. Thus, repair of nontranscribed regions of DNA may have little impact on cell survival. One hypothesis to explain the phenotypic heterogeneity of mutants in group 2 is that the (hamster) Ercc2 protein has at least two functions. One function, perhaps the ability to interact with the repair -omplex, may 
be essential for all repair. Mutants such as UV5 and UV57 would lack this function. Another function may be one that helps determine active gene repair. The other mutants, $\mathrm{V}-\mathrm{H} 1$ and UVL1, could lack this function while retaining part of the generalized repair function. In these mutants the remaining repair would no longer be channeled to active genes. A third possible function associated with the Ercc2 repair protein was suggested above, one required for cell growth. The possibility of additional functions is suggested by the finding that mutations in $R A D 3$ can inctease spontaneous mitotic recombination and mutation without affecting UV sensitivity (Montelone et al., 1988).

Other Hanster Mutants That are Hypersensitive to Crosslinking Agents

The most extreme sensitivities found among mammalian repair mutants pertain to DNA cross-linking agents. This finding suggests that cross-links are very toxic if not repaired and that cells normally have highly efficient mechanisms for coping with these lesions. In view of the 10- to 100-fold increases in mutant sensitivity, it appears that almost all cross-links are normally rendered innocuous, either by unhooking or actual excision. The UV sensitive mutants presented in Table 1 all show varying degrees of hypersensitivity to the cross-linking agent MMC. These results point to overlap of the genetic pathways for repairing cross-links and UV damage. However, cross-link repair appears to require some genes that play only a minor role, or none at all, in UV dimer repair.

Table 4 lists several reported mutants (not a compehensive list) that have the property of substantial hypersensitivity to the cross-linking agent MMC while showing little or no change in UV sensitivity. Some of these mutants show extreme degrees of MMC sensitivity, similar to the nucleotide excision repair mutants in UV complementation groups 1 and 4 of Table 1. For example, irs1SF, irs1, and V-C8 have 50-100 fold hypersensitivity. Interestingly, irs1SF and irs I were both isolaved on the basis of their increased sensitivity to ionizing radiation, with each mutant being 2- to 3-fold more sensitive than its parental line. (These findings point out that the most pronounced aspect of a mutant's phenotype may be distantly related to its mode of 
isolation.) It is clear that MMC-sensitive mutants belong to many different complementation groups. For example, irsl, irs1SF, UV20, and UV41 are in different groups (L. Thompson and N. Jones, unpublished data). Further analysis indicates additional groups (Robson and Hickson, 1986; M. Zdrienicka, personal communication).

\section{ACKNOWLEDGMENTS}

The work was performed under the auspices of the U.S. Department of Energy by the Lawrence Livermore National Laboratory under contract No.W-7405-ENG-48.

\section{REFERENCES}

Bohr, V.A., Smith, C.A., Okumoto, D.S., and Hanawalt, P.C., 1985, DNA repair in an active gene: removal of pyrimidine dimers from the DHFR gene of CHO cells is much more efficient than in the genome overall, Cell, 40:359-369.

Bohr, V.A., Okumoto, D.S., and Hanawalt, P.C., 1986, Survival of UV-irradiated mammalian cells correlates with efficient DNA repair in an essential gene, Proc. Natl. Acad. Sci. U.S.A., 83: 3830-3833.

Bohr, V.A., Phillips, D.H., and Hanawalt, P.C., 1987, Heterogeneous DNA damage and repair in the mammalian genome, Cancer Res., 47: 6426-6436.

Busch, D.B., Cleaver, J.E., and Glaser, D.A., 1980, Large-scale isolation of UV-sensitive clones of CHO cells, Somat. Cell Genet., 6: 407-418.

Busch, D.B., Thompson, L.H., Greiner, C., Lewis, K., and Ford, R., 1988, Summary of complementation group data for UV-sensitive single and double mutants of CHO cells isolated by large-scale screening, in preparation.

Chen, C., and Okayama, H., 1987, High-efficiency transformation of mammalian cells by plasmid DNA, Mol. Cell. Biol., 7: 2745-2752.

Collins, A., Johnson, R.T., 1987, DNA repair mutants of higher eukaryores, J. Cell Sci., Suppl. 6, 61-82. 
Dulhanty, A.M., Rubin, J.S., and Whitmore, G.F., 1988, Complementation of the DNA repair defect in a CHO mutant by human DNA that lacks highly abundart repetitive sequences, Mutat. Res., in press.

Fischer, E., Keijzer, W., Thielmann, H.W., Popanda, O., Bohnert, E., Edler, L., Jung, E.G., and Bootsma, D., 1985, A ninth complementation group in xeroderma pigmentosum, XP I, Mutat. Res., 145: 217-225.

Friedberg, E.C., 1985, "DNA Repair," W.H. Freeman, New York.

Friedberg, E.C., 1987, The molecular biology of nucleotide excision repair of DNA: recent progress, J. Cell Sci., Suppl. 6: 1-23.

Fuller, L.F., and Painter, R.B. 1988, A Chinese hamster ovary cell line hypersensitive to ionizing radiation and deficient in repair replication, Mutat. Res., 193: 109-121.

Gottesman, M.M., 1985, "Molecular Cell Genetics," John Wiley \& Sons, New York.

Hanawalt, P.C., and Sarasin, A., 1986, Cancer-prone hereditary diseases with DNA processing abnormalities, Trends Genet., 2: 124-129.

Hickson, I.D., and Harris, A.L., 1988, Mammalian DNA repair -- use of mutants hypersensitive to cytotoxic agents, Trends Genet., 4: 101-106.

Higgins, D.R., Prakash, S., Reynolds, P., Polakowska, R., Weber, S., Prakash, L., 1983, Isolation and characterization of the RAD3 gene of Saccharomyces cerevisiae and inviability of rad3 deletion mutants, Proc. Nati. Ácad. Sci. Ü.Ŝ.Á., 80̂: 5680-5684.

Hori, T.A., Shiomi, T., and Sato, K., 1983, Human chromosome 13 compensates a DNA repair defect in UV-sensitive mouse cells by a mouse-human cell hybridization, Proc. Natl. Acad. Sci. U.S.A., 80: 5655-5659.

Hoy, C.A., Thompson, L.H., Mooney, C.L., and Salazar, E.P., 1985, Defective cross-link removal in Chinese hamster cell mutants hypersensitive to bifunctional alkylating agents, Cancer Res., 45: 1737-1743. 
Johnson, R.T., Elliott, G.C., Squires, S., and Joysey, V.C., 1988, Lack of complementation between xeroderma pigmentosum complementation groups $\mathrm{D}$ and $\mathrm{H}$, submitted.

Jones, N.J., Cox, R., and Thacker, J., 1987, Isolation and cross-sensitivity of X-raysensitive mutants of V79-4 hamster cells, Mutat. Res., 183: 279-286.

Lambert, C., Couto, L.B., Weiss, W.A., Schultz, R.A., Thompson, L.H., and Friedberg, E.C, 1988, A yeast DNA repair gene partially complements defective excision repair in mammalian cells, EMBO J., in press.

Mitchell, D.L., Humphrey, R.M., Adair, G.A., Thompson, L.H., and Clarkson, J.M., 1988, Repair of (6-4)photoproducts correlates with split-dose recovery in UV-irradiated normal and hypersensitive rodent cells, Mutat. Res., 193: 53-63.

Montelone, B.A., Hoekstra, M.F., and Malone, R.E., 1988, Spontaneous mitotic recombination in yeast: The hyper-recombinational reml mutations are alleles of the RAD3 gene, Genetics, 119: 289-301.

Naumovski, L., and Friedberg, E.C., 1983, A DNA repair gene requires for the incision of damaged DNA is essential for viability in yeast., Proc. Natl. Acad. Sci. U.S.A., 80: 48184821.

Naumovski, L., and Friedberg, E.C., 1986, Analysis of the essential and excision repair

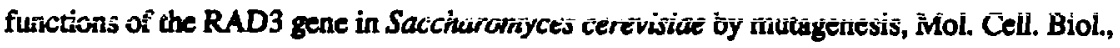
6: 1218-1227.

MacInnes, M.A., Okinaka, R.T., Chen, D.J., Nickols, J.W., Tesmer, J.G., McCoy, L.S., and Strniste, G.F., 1988, Molecular-genetic evidence for identification of the ERCC-5 human DNA excision repair gene, J. Cell. Biochem., Suppl. 12A: 319.

Robson, C.N., Harris, A.L., and Hickson, I.D., 1985, Isolation and characterization of Chinese hamster ovary cell lines sensitive to mitomycin $C$ and bleomycin, Cancer Res., 45: 5304-5309. 
Robson, C.N., and Hickson, I.D., 1986, Genetic analysis of mitomcyin C-sensitive mutants of a Chinese hamster ovary cell line, Mutat. Res., 163:201-208.

Sato, K. and Setlow, R.B., 1981, DNA repair in a UV-sensitive mutant of a mouse cell line, Mutat. Res., 84: 443-455.

Schultz, R.A., Saxon, P.J., Chao, C.C.-K., and Friedberg, E.C., 1988, Phenotypic complementation of xeroderma pigmentosum (XP) cells following microcell-mediated chromosome transfer, in: "Mechanisms and Consequences of DNA Damage Processing," UCLA Symposia on Mol. Biol., New Series, Vol. 83, E. Friedberg and P. Hanawalt, eds., Alan R. Liss, New York, in press.

Shiomi, T., Hieda-Shiomi, N., and Sato, K., 1982, Isolation of UV-sensitive mutants of mouse L5178Y cells by a cell suspension spotting method, Somat. Cell Genet., 8: 329 345.

Siciliano, M.J., Bachinski, L., Dolf, G., Carrano, A.V., and Thompson, L.H., 1987, Chromosomal assignments of human DNA repair genes that complement Chinese hamster ovary (CHO) cell mutants, Cytogenet. Cell Genet., 46: 691-692.

Siciliano, M.J., Carrano, A.V., and Thompson, L.H., 1986, Assignment of a human DNArepair gene associated with sister-chromatid exchange to chromosome 19, Mutat. Res., 174: 303-308.

Stamato, T.D., and Waldren, C.A., 1977, Isolation of UV-sensitive variants of CHO-K1 by nylon cloth replica plating, Somat. Cell Genet., 3: 431-440.

Sung, P., Prakash, L., Matson, S.W., and Prakash, L., 1987a, RAD3 protein of Saccharomyces cerevisiae is a DNA helicase, Proc. Natl. Acad. Sci. U.S.A., 84, 89518955.

Sung, P., Prakash, L., Weber, S., and Prakash, L., 1987b, The RAD3 gene of Saccharomyces cerevisiae encodes a DNA-dependent ATPase, Proc. Natl. Acad. Sci. U.S.A., 84: 6045-6049. 
Thacker, J., 1981, The chromosomes of a V79 Chinese hamster line and a mutant subline lacking HPRT activity, Cytogenet. Cell Genet., 29: 16-25.

Thompson, L.H., 1988, Use of Chinese hamster ovary cell mutants to study human DNA repair genes, in: "DNA Repair, Vol. 3," E. Friedberg and P. Hanawalt, eds., Marcel Dekker, New York, pp. 115-132.

Thompson, L.H., Bachinski, L., Weber, C.A., Stallings, R., and Siciliano, M.J., 1988a, Complementation of repair gene mutations on the hemizygous chromosome 9 in CHO cells: a third DNA repair gene on human chromosome 19, in preparation for Genomics.

Thompson, L.H., Brookman, K.W., Dillehay, L.E., Mooney, C.L., and Carrano, A.V., 1982a, Hypersensitivity to mutation and sister-chromatid-exchange induction in CHO cell mutants defective in incising DNA containing UV lesions, Somat. Cell Genet., 8: 759-773.

Thompson, L.H., Brookman, K.W., Dillehay, L.E., Carrano, A.V., Mazrimas, J.A., Mooney, C.L., and Minkler, J.L., 1982b, A CHO-cell strain having hypersensitivity to mutagens, a defect in DNA strand-break repair, and an extraordinary baseline frequency of sister chromatid exchange, Mutat. Res., 95: 427-440.

Thompson, L.H., Brookman, K.W., Jones, N.J., Collins, C.C., and Carrano, A.V., 1988b, Molecular cloning and properties of the human gene, XRCCI, that corrects a mutation causing sister chromatid exchange, in preparation.

Thompson, L.H., Brockman, K.W., and Mooney, C.L., 1984, Repair of DNA adducts in asynchronous CHO cells and the role of repair in cell killing and mutation induction in synchronous cells treated with 7-bromomethylbenz[a]anthracene, Somat. Cell Mol. Genet. 10: 183-194.

Thompson, L.H., Busch, D.B., Brookman, K., Mooney, C.L., and Glaser, D.A., 1981, Genetic diversity of UV-sensitive DNA repair mutants of Chinese hamster ovary cells, Proc. Natl. Acad. Sci. U.S.A., 78: 3734-3737.

Thompson, L.H., and Carrano, A.V., 1983, Analysis of mammalian cell mutagenesis and DNA repair using in vitro selected CHO cell mutants, in: "Cellular Responses to DNA 
Damage, UCLA Symposia on Molecular and Cellular Biology," New Series, Vol. 11, E.C. Friedberg and B.A. Bridges, eds., Alan R. Liss, New York, 125-143.

Thompson, L.H., Carrano, A.V., Sato, K., Salazar, E.P., White, B.F., Stewart, S.A., Minkler, J.L., and Siciliano, M.J., 1987a, Identification of nucleotide-excision-repair genes on human chromosomes 2 and 13 by functional complementation in hamster-human hybrids, Somat. Cell Mol. Genet., 13: 539-551.

Thompson, L.H., Mitchell, D.L., Regan, J.D., Bouffler, S.D., Stewart, S.A., Carrier, W.L., Nairn, R.S., and Johnson, R.T., 1988c, CHO mutant UV61 removes (6-4) photoproducts but not cyclobutane dimers, submitted to Mutagenesis.

Thompson, L.H., Mooney, C.L., Burkhart-Schultz, K., Carrano, A.V., and Siciliano, M.J., 1985, Correction of a nucleotide-excision-repair mutation by human chromosome 19 in hamster-human hybrid cells, Somat. Cell Mol. Genet, 11: 87-92.

Thompson, L.H., Rubin, J.S., Cleaver, J.E., Whitmore, G.F., and Brookman, K., 1980, A screening method for isolating DNA repair-deficient mutants of CHO cells, Somat. Cell Genet., 6, 391-405.

Thompson, L.H., Salazar, E.P., Brookman, K.W., Collins, C.C., Stewart, S.A., Busch, D.B., and Weber C.A., 1987b, Recent progress with the DNA repair mutants of Chinese hamster ovary cells, J. Cell Sci., Suppl. 6, 97-110.

Thompson, L.H., Shiomi, T., Salazar, E.P., and Stewart, S.A., 1988d, An eighth complementation group of rodent cells hypersensitive to ultraviolet radiation, Somat. Cell Mol. Genet., 14, in press.

Thompson, L.H., Weber, C.A., and Carrano, A.V., 1988e, Human DNA repair genes, in: "Mechanisms and Consequences of DNA Damage Processing," UCLA Symposia on Mol. Biol., New Series, Vol. 83, E. Friedberg and P. Hanawalt, eds., Alan R. Liss, New York, in press.

van Duin, M., de Wit, J., Odijk, H., Westerveld, A., Yasui, A., Koken, M.H.M., Hoeijmakers, J.H.J., and Bootsma, D., 1986, Molecular characterization of the human 
excision repair gene ERCC-1: cDNA cloning and amino acid homology with the yeast DNA repair gene RAD10, Cell, 44: 913-923.

van Duin, M., Koken, M.H.M., van den Tol, J., ten Dijke, P., Odijk, H., Westerveld, A., Bootsma, D., and Hoeijmakers, J.H.J., 1987, Genomic characterization of the human DNA excision repair gene ERCC1, Nuc. Acids. Res., 15: 9195-9213.

van Duin, M., Janssen, J.H., de Wit, J., Hoeijmakers, J.H.J., Thompson, L.H., Bootsma, D., and Westerveld, A., 1988, Transfection of the cloned human excision repair gene ERCC-1 to UV-sensitive CHO mutants only corrects the repair defect in complementation group-2 mutants, Mutat. Res., 193: 123-130.

Waldren, C., Snead, D., and Stamato, T., 1983, Restoration of normal resistance to killing and of post-replication recovery (PRR) in CHO-UV-1 cells by transformation with hamster or human DNA, in: "Cellular Responses to DNA Damage, UCLA Symposia on Molecular and Cellular Biology," New Series, Vol. 11, E.C. Friedberg and B.A. Bridges, eds., Alan R. Liss, New York, 637-646.

Weber, C.A., Salazar, E.P., Stewan, S.A., and Thompson, L.H., 1988a, Molecular cloning and biological characterization of a human gene, ERCC2, that corrects the nucleotide excision repair defect in CHO UV5 cells, Mol. Cell Biol., 8: 1137-1146.

Weber, C.A., Salezar, E.P., Stewart, S.A., and Thompson, L.H., 1988b, Cloning of a human gene and its cDNA that correct the nucleotide excision repair defect in CHO complementation group 1, J. Cell. Biochem., Suppl. 12A: 329.

Weber, C.A., Salazar, E.P., Stewart, S.A., and Tnompson, L.H., 1988c, ERCC2: cDNA cloning and molecular characterization of a human nucleotide excision repair gene with homology to the yeast $R A D 3$ gene, in preparation.

Weeda, G., van Ham, R.C.A., Masurel, R., Hoeijmakers, J.H.J., Westerveld, A., Boctsma, D., and van der Eb, A.J., 1988, Molecular cloning of part of the human excision repair gene ERCC-3, J. Cell. Biochem., Suppl. 12A: 303. 
Westerveld, A., Hoeijmakers, J.H.J., van Duin, M., de Wit, J., Odijk, H., Pastink, A., Wood, R.D., and Bootsma, D., 1984, Molecular cloning of a human DNA repair gene, Nature, 310: 425-429.

Wood, R.D., and Burki, H.J., 1982, Repair capability and the cellular age response for killing and mutation induction after UV, Mutat. Res., 95: 505-514.

Zdzienicka, M.Z., and Simons, J.W.I.M., 1987, Mutagen-sensitive cell lines are obtained with a high frequency in V79 Chinese hamster cells, Mutat. Res., 178: 235-244.

Zdzienicka, M.Z., van der Shans, G.P., Westerveld, A., van Zeeland, A.A., Simons, J.W.I.M., 1988^, Phenotypic heterogeneity within the first complementation group of UVsensitive mutants of Chinese hamster cells, Mutat. Res., 193: 31-41.

Zdzienicka, M.Z., van der Shans, G.P., and Simons, J.W.I.*Z., 1988b, Identification of a new seventh complementation group of UY-sensitive mutants in Chinese hamster cells, Mutat. Res., 194:165-170. 